China, the Indian subcontinent/South Asia, globalization, nonproliferation and security affairs. Aims to advance co-operation between nations and promote active international engagement by the USA and become 'the first truly multinational-ultimately global-think tank'. Offices in Washington, D.C., Moscow, Beijing, Beirut and Brussels.

Address: 1779 Massachusetts Ave., NW, Washington, D.C., 20036-2103, USA.

Website: http://www.carnegieendowment.org

President: Jessica T. Mathews.

\section{Cato Institute}

Founded 1977. Non-profit public policy research foundation based on the principles of the American Revolution-limited government, free markets, individual liberty and peace. Comprises Centers for Constitutional Studies, Educational Freedom, Global Liberty and Prosperity, Representative Government and Trade Policy Studies.

Address: 1000 Massachusetts Ave., NW, Washington, D.C., 20001-5403, USA.

Website: http://www.cato.org

President: Edward H. Crane.

\section{Center for Strategic and International Studies}

Founded in 1962 during the Cold War to find ways for the USA to sustain its prominence and prosperity as a force for good in the world. Bipartisan, non-profit organization that conducts research and analysis and develops policy initiatives that look into the future and anticipate change. Research focuses on defence and security, energy and climate change, global health, global trends and forecasting, governance, human rights, technology, and trade and economics.

Address: 101800 K St., NW, Washington, D.C., 20006, USA.

Website: http://www.csis.org

President: John J. Hamre.

\section{Centre for Economic Policy Research}

Founded 1983. Non-profit, educational research network that promotes independent, objective analysis and public discussion of open economies and the relations among them. Programmes: development economics; financial economics; industrial organization; international macroeconomics; international trade and regional economics; labour economics; public policy.

Address: 77 Bastwick St., London EC1V 3PZ, UK.

Website: http://www.cepr.org

Director: Mathias Dewatripont.

\section{Centre for European Policy Studies}

Founded 1983. Independent institute specializing in European affairs. Research programmes: economic and social welfare policies; energy, climate change and sustainable development; EU neighbourhood, foreign and security policy; financial markets and institutions; justice and home affairs; politics and European institutions; regulatory policy; trade developments and agricultural policy.

Address: 1 Place du Congrès, B-1000 Brussels, Belgium.

Website: http://www.ceps.eu

Director: Daniel Gros.

\section{Centre for European Reform}

Pro-European think tank focusing on political, economic and social challenges facing Europe. Research topics: Britain and the
EU; EU budget; EU foreign policy; EU institutions; justice and home affairs; economics and finance; energy and environment; education and research; the euro; security and defence policy; enlargement and Turkey; neighbourhood policy; transatlantic relations; Russia; China; the Middle East; Arab Reform initiative.

Address: 14 Great College St., London SW1P 3RX, UK.

Website: http://www.cer.org.uk

Director: Charles Grant.

\section{Centre for Independent Studies}

Founded 1976. Leading independent public policy think tank within Australasia. Promotes individual liberty and choice, a free market economy, democratic government under the rule of law, and an autonomous and free civil society. Research areas: economic policy; foreign policy; social policy; government and politics; law; ideas about liberty; New Zealand.

Address: Lvl 4, 38 Oxley St, St Leonards, NSW, Australia 2065.

Website: http://www.cis.org.au

Executive Director: Greg Lindsay.

\section{Centre for Strategic and International Studies}

Founded 1971. Independent non-profit organization focusing on policy-oriented studies and dialogue on domestic (Indonesian) and international issues. Research areas: economics, politics and social change, and international relations.

Address: The Jakarta Post Building, 3rd Floor, Jl. Palmerah

Barat 142-243, Jakarta 10270, Indonesia.

Website: http://www.csis.or.id

Executive Director: Rizal Sukma.

\section{Chatham House (Royal Institute of International Affairs)}

Founded 1920. Leading independent think tank whose research centres on three areas: energy, environment and resource governance; international economics; regional and security studies. Established the 'Chatham House Rule' that aids free and open debate by allowing for anonymity of speakers at meetings. Sister organization of Council on Foreign Relations in New York.

Address: 10 St James' Square, London SW1Y 4LE, UK.

Website: http://www.chathamhouse.org.uk

Director: Dr Robin Niblett.

\section{Chinese Academy of Social Sciences}

Founded 1977. China's highest academic research organization in the fields of philosophy and social sciences. Comprises 32 research institutes, three research centres and a graduate school. Research covers 120 key areas.

Address: 5 Jianguomennei Dajie, Beijing 100732, China.

Website (Chinese only): http://www.cass.net.cn

President: Chen Kuiyuan.

\section{Civitas (Institute for the Study of Civil Society)}

Founded 2000. Independent think tank that also provides primary education for children and provides teaching materials and speakers for schools. Research areas: crime; constitution; education; Europe; family; health reform; immigration.

Address: First Floor, 55 Tufton St., London SW1P 3QL, UK.

Website: http://www.civitas.org.uk

Director: Dr David G. Green. 